\title{
PENGARUH PERTUMBUHAN PENJUALAN DAN PERPUTARAN PIUTANG TERHADAP PROFITABILITAS PADA PERUSAHAAN MAKANAN DAN MINUMAN YANG TERDAFTAR DI BURSA EFEK INDONESIA
}

\author{
Oleh : \\ Daniel Agustinus Sidabutar \\ S1 Akuntansi \\ Liper Siregar, Jubi, Astuti
}

Abstrak

Tujuan dari penelitian ini adalah: 1. Untuk mengetahui gambaran pertumbuhan penjualan, perputaran piutang dan profitabilitas pada Perusahaan Sub Sektor Makanan dan Minuman yang terdaftar di Bursa Efek Indonesia. 2. Untuk mengetahui pengaruh pertumbuhan penjualan dan perputaran piutang terhadap profitabilitas pada Perusahaan Sub Sektor Makanan dan Minuman yang terdaftar di Bursa Efek Indonesia baik secara simultan maupun parsial.

Hasil penelitian dapat disimpulkan sebagai berikut: 1. Rata-rata pertumbuhan penjualan adalah sebesar adalah 0,1078, Rata-rata perputaran piutang sebesar 9,4204 kali dan Rata-rata Net Profit Margin (NPM) sebesar 0,1048 kali. 2. Hasil pengujian regresi linier berganda adalah $\hat{\mathbf{Y}}=\mathbf{0 , 1 9 3 -}$ $\mathbf{0}, \mathbf{2 5 4} \mathrm{X}_{1}-\mathbf{0}, \mathbf{0 0 6} \mathrm{X}_{2}$ artinya pertumbuhan penjualan dan perputaran piutang berpengaruh negatif terhadap profitabilitas. 3. Hasil analisis koefisien korelasi adalah sebesar 0,463 artinya terdapat hubungan yang sedang antara Net Profit Margin (NPM) dengan pertumbuhan penjualan dan perputaran piutang. Koefisien determinasi adalah sebesar 0,215 artinya 21,5\% Net Profit Margin (NPM) dapat dijelaskan oleh pertumbuhan penjualan dan perputaran piutang. 4. Hipotesis penelitian $\mathrm{H}_{0}$ ditolak, yang berarti bahwa pertumbuhan penjualan dan perputaran piutang berpengaruh signifikan terhadap profitabilitas pada Perusahaan Sub Sektor Makanan dan Minuman yang terdaftar di Bursa Efek Indonesia periode 2014-2016 baik secara simultan maupun parsial.

Kata Kunci: Pertumbuhan Penjualan, Perputaran Piutang dan Profitabilitas

Abstract

The purpose of this research are: 1. To determine the description of the of sales growth, receivable turnover and profitability at the Food and Beverage Sub-Sector, listed in Indonesia Stock Exchange period 2014-2016. 2. To determine the influence of sales growth and receivable turnover To The profitability at the Food and Beverage Sub-Sector, listed in Indonesia Stock Exchange period 2014-2016 either simultaneously or partially.

The results of this research are 1. the average sales growth is 0,1078 , the average receivable turnover is 9,4204 and average profitability is 0,1048. 2. The test results of multiple linier regression is

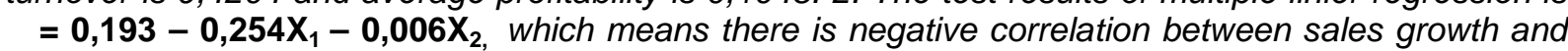
receivable turnover with profitability 3 . The correlation of coefficient is 0,463 means that there is a medium relation between sales growth and receivable turnover with profitability. The coefficient of determination is 0,215 which means 21,5\% of Net Profit Margin (NPM) can be explained by sales growth and receivable turnover. 4. Research hypothesis $\mathrm{H}_{0}$ is rejected, which means sales growth and receivable turnover have a significant effect on Net Profit Margin (NPM) at the Food and Beverage Sub-Sector, listed in Indonesia Stock Exchange period 2014-2016 either simultaneously or partially.

Keywords: Sales Growth, Receivable Turnover and Profitability

\section{A. PENDAHULUAN}

\section{Latar Belakang Masalah}

Pada umumnya usaha yang dilakukan oleh setiap perusahaan untuk meningkatkan profitabilitas adalah dengan penjualan. Apabila penjualan perusahaan tinggi maka profitabilitas perusahaan akan lebih baik. Demikian pula apabila penjualan rendah, menunjukkan bahwa perusahaan tidak produktif. Selain dipengaruh pertumbuhan penjualan, perputaran piutang juga mempengaruhi naik turunnya tingkat profitabilitas suatu perusahaan. Perputaran piutang menunjukkan berapa kali piutang timbul sampai piutang tersebut kembali ke kas dan

dimanfaatkan kembali untuk operasi
perusahaan. Profitabilitas merupakan
kemampuan perusahaan dalam mencari
keuntungan. Profitabilitas mencerminkan
kemampuan perusahaan untuk menghasilkan
laba baik dari penjualan yang dilakukan
perusahaan maupun aset yang dimiliki
perusahaan. Jumlah laba yang diperoleh secara
teratur serta laba yang diperoleh cenderung
untuk meningkat merupakan faktor yang sangat
penting dalam menilai kinerja suatu perusahaan
Peningkatan pada pertumbuhan penjualan
dapat mempengaruhi profitabilitas tergantung
bagaimana perusahaan dalam mengelola


aktivitas penjualannya terhadap besarnya profitabilitas perusahaan. Aktivitas penjualan perusahaan yang juga berdampak terhadap timbulnya piutang dalam perusahaan.

Tabel 1

Rata-rata Pertumbuhan Penjualan,

Perputaran Piutang dan Net Profit Margin

(NPM) pada Perusahaan Sub Sektor

Makanan dan Minuman yang Terdaftar di Bursa Efek Indonesia

Periode 2014-2016

\begin{tabular}{|c|c|r|r|}
\hline Tahun & $\begin{array}{c}\text { Rata-rata } \\
\text { Pertumbuhan } \\
\text { Penjualan (x) }\end{array}$ & $\begin{array}{c}\text { Rata-rata } \\
\text { Perputaran } \\
\text { Piutang (x) }\end{array}$ & $\begin{array}{r}\text { Rata-rata } \\
\text { Net Profif } \\
\text { Margin (x) }\end{array}$ \\
\hline 2014 & 0,1720 & 9,4017 & 0,0989 \\
\hline 2015 & 0,0319 & 9,3221 & 0,0966 \\
\hline 2016 & 0,1195 & 9,5374 & 0,1190 \\
\hline
\end{tabular}

Sumber: www.idx.co.id (data diolah)

Dari Tabel 1, rata-rata pertumbuhan penjualan cenderung menurun sementara ratarata Net Profit Margin (NPM) mengalami penurunan. Hasil ini tidak sejalan dengan pendapat Husnan (2000:387), bahwa pertumbuhan penjualan dapat juga mempengaruhi profitabilitas perusahaan. Semakin tingginya penjualan bersih yang dilakukan oleh perusahaan dapat mendorong semakin tingginya laba kotor yang mampu diperoleh, sehingga dapat mendorong semakin tingginya profitabilitas suatu perusahaan.

Dari Tabel 1, rata-rata perputaran piutang cenderung meningkat dan rata-rata $\mathrm{Net}$ Profit Margin (NPM) mengalami peningkatan. Hasil ini tidak sejalan dengan pendapat Riyanto (2010:85), bahwa semakin besar proporsi penjualan kredit dari keseluruhan penjualan memperbesar jumlah investasi dalam piutang. Dengan semakin besarnya volume penjualan kredit setiap tahunnya, maka perusahaan itu harus menyediakan investasi yang lebih besar lagi dalam piutang. Semakin besarnya jumlah piutang maka akan semakin besar risiko, tetapi akan memperbesar profitabilitas.

\section{Rumusan Masalah}

Adapun rumusan masalah adalah sebagai berikut:

a. Bagaimana gambaran pertumbuhan penjualan, perputaran piutang dan profitabilitas pada perusahaan Sub Sektor Makanan dan Minuman yang terdaftar di Bursa Efek Indonesia.

b. Bagaimana pengaruh pertumbuhan penjualan dan perputaran piutang terhadap profitabilitas pada perusahaan Sub Sektor Makanan dan Minuman yang terdaftar di Bursa Efek Indonesia baik secara simultan maupun parsial.

\section{Tujuan Penelitian} berikut:
1. Untuk mengetahui gambaran pertumbuhan penjualan, perputaran piutang dan profitabilitas pada Perusahaan Sub Sektor Makanan dan Minuman yang terdaftar di Bursa Efek Indonesia.

2. Untuk mengetahui pengaruh pertumbuhan penjualan dan perputaran piutang terhadap profitabilitas pada Perusahaan Sub Sektor Makanan dan Minuman yang terdaftar di Bursa Efek Indonesia baik secara simultan maupun parsial.

\section{Metodologi Penelitian}

Objek penelitian pada Perusahaan Sub Sektor Makanan dan Minuman yang terdaftar di Bursa Efek Indonesia. Penelitian ini dilakukan dengan menggunakan data skunder, untuk mendapatkan data informasi yang dibutuhkan dalam penelitian ini, maka dilakukan dengan cara mengakses dari situs http://www.idx.co.id

Desain penelitian yang digunakan dalam penelitian ini adalah penelitian kepustakaan (library research). Teknik analisa data yang digunakan dalam penelitian ini adalah Uji Asumsi Klasik, Analisa Deskriptif Kualitatif, Analisa Deskriptif Kuantitatif

\section{B. LANDASAN TEORI}

\section{Laporan Keuangan}

Menurut Menurut Kasmir (2012:7), laporan keuangan adalah laporan yang menunjukkan kondisi keuangan perusahaan saat ini atau dalam suatu periode tertentu. Menurut Martani (2012:62), laporan keuangan merupakan informasi bagi penggunanya, terutama pemilik perusahaan, investor, kreditor, dan juga manajemen untuk mengambil keputusankeputusan terkait perusahaan di masa mendatang.

Menurut Kasmir (2012:11), beberapa tujuan laporan atas penyusunan laporan keuangan yaitu:

a. Memberikan informasi tentang jenis jumlah aktiva (harta) yang dimiliki perusahaan saat ini.

b. Memberikan informasi tentang jenis jumlah kewajiban dan jumlah modal yang dimiliki perusahaan saat ini.

c. Memberikan informasi tentang jenis dan jumlah pendapatan yang diperoleh pada suatu periode tertentu

\section{Analisis Rasio Keuangan}

Menurut Kasmir (2012:104), rasio keuangan merupakan kegiatan membandingkan angkaangka yang ada dalam laporan keuangan dengan cara membagi satu angka dengan angka yang lainnya. Perbandingan dapat dilakukan antara satu komponen dengan komponen dalam satu laporan keuangan atau antara komponen yang ada diantara laporan keuangan. Kemudian angka yang 
diperbandingkan dapat berupa angka-angka dalam satu periode maupun beberapa periode.

Menurut Brigham dan Joel (2010:133), rasio keuangan berguna untuk mengantisipasi kondisi masa depan, yang lebih penting lagi adalah sebagai titik awal untuk merencanakan tindakan-tindakan yang akan memperbaiki kinerja di masa depan.

\section{Pertumbuhan Penjualan}

Menurut Harahap (2008:310), pertumbuhan penjualan adalah persentasi kenaikkan penjualan tahun ini dibanding dengan tahun lalu, semakin tinggi akan semakin baik.

Menurut Bayangkara (2014:151) Faktorfaktor yang mempengaruhi pertumbuhan penjualan antara lain:

a. Produk

Segala sesuatu yang ditawarkan kepada pasar untuk menarik perhatian dan memuaskan keinginan atau kebutuhan.

b. Harga

Merupakan jumlah uang yang harus dibebankan konsumen untuk mendapatkan manfaat dari memiliki atau memanfaatkan suatu barang

c. Distribusi

Distribusi merupakan jaringan organisas yang menghubungkan produsen dan konsumen.

d. Promosi

Untuk mengkomunikasikan produk dan pelayanan yang disediakan kepada pelanggan dan keberadaan suatu produk.

\section{Perputaran Piutang}

Menurut Harahap (2008:308), perputaran piutang adalah seberapa cepat penagihan piutang. Semakin besar akan semakin baik karena penagihan piutang dilakukan dengan cepat.

Faktor-faktor tersebut seperti yang dikemukakan oleh Riyanto (2010:85), adalah sebagai berikut:

a. Volume penjualan kredit

b. Syarat pembayaran penjualan kredit

c. Ketentuan tentang pembatasan kredit

d. Kebijaksanaan dalam mengumpulkan piutang

e. Kebiasaan membayar dari para pelanggan

\section{Profitabilitas}

Menurut Sudana (2011:22), rasio profitabilitas adalah rasio yang mengukur kemampuan perusahaan untuk menghasilkan laba dengan menggunakan sumber-sumber yang dimiliki perusahaan, seperti aset, modal dan penjualan perusahaan. Rasio NPM mengukur kemampuan perusahaan untuk menghasilkan laba setelah pajak dari penjualan yang dilakukan perusahaan
Menurut Kasmir (2012:52), terdapat beberapa faktor-faktor yang mempengaruhi profitabilitas yaitu:

a. Perputaran modal kerja

b. Perputaran kas

c. Perputaran piutang

6. Pengaruh Pertumbuhan Penjualan dan Perputaran Piutang terhadap Profitabilitas

Menurut Husnan (2000:387), bahwa pertumbuhan penjualan dapat juga mempengaruhi profitabilitas perusahaan. Semakin tingginya penjualan bersih yang dilakukan oleh perusahaan dapat mendorong semakin tingginya laba kotor yang mampu diperoleh, sehingga dapat mendorong semakin tingginya profitabilitas suatu perusahaan.

Sedangkan menurut Riyanto (2010:85), bahwa semakin besar proporsi penjualan kredit dari keseluruhan penjualan memperbesar jumlah investasi dalam piutang. Dengan semakin besarnya volume penjualan kredit setiap tahunnya, maka perusahaan itu harus menyediakan investasi yang lebih besar lagi dalam piutang. Semakin besarnya jumlah piutang maka akan semakin besar risiko, tetapi akan memperbesar profitabilitas.

\section{PEMBAHASAN}

1. Analisis

a. Analisis Deskripsi Kualitatif

1) Analisis Pertumbuhan Penjualan pada

Perusahaan Sub Sektor Makanan dan Minuman yang Terdaftar di Bursa Efek Indonesia Periode 2014-2016

Rata-rata pertumbuhan penjualan pada Perusahaan Sub Sektor Makanan dan Minuman yang Terdaftar di Bursa Efek Indonesia periode 2014-2016 pada Tabel 2 sebagai berikut:

Tabel 2

Gambaran Pertumbuhan Penjualan pada

Perusahaan Sub Sektor Makanan dan Minuman yang Terdaftar di Bursa Efek Indonesia

\section{Periode 2014-2016}

\begin{tabular}{|c|c|c|c|c|}
\hline $\begin{array}{c}\text { Kode } \\
\text { Emiten }\end{array}$ & $\begin{array}{c}\mathbf{2 0 1 4} \\
(\mathbf{x})\end{array}$ & $\begin{array}{c}\mathbf{2 0 1 5} \\
(\mathbf{x})\end{array}$ & $\begin{array}{c}\mathbf{2 0 1 6} \\
(\mathbf{x})\end{array}$ & $\begin{array}{c}\text { Rata-rata } \\
(\mathbf{x})\end{array}$ \\
\hline AISA & 0,2670 & 0,1694 & 0,0890 & $\mathbf{0 , 1 7 5 1}$ \\
\hline CEKA & 0,4621 & $-0,0584$ & 0,1807 & $\mathbf{0 , 1 9 4 8}$ \\
\hline DLTA & 0,0141 & $-0,2044$ & 0,1079 & $\mathbf{- 0 , 0 2 7 5}$ \\
\hline ICBP & 0,1964 & 0,0572 & 0,0859 & $\mathbf{0 , 1 1 3 2}$ \\
\hline INDF & 0,1015 & 0,0074 & 0,0420 & $\mathbf{0 , 0 5 0 3}$ \\
\hline MLBI & $-0,1610$ & $-0,0978$ & 0,2103 & $-\mathbf{0 , 0 1 6 2}$ \\
\hline MYOR & 0,1790 & 0,0458 & 0,2383 & $\mathbf{0 , 1 5 4 4}$ \\
\hline ROTI & 0,2489 & 0,1565 & 0,1598 & $\mathbf{0 , 1 8 8 4}$ \\
\hline SKBM & 0,1420 & $-0,0800$ & 0,1019 & $\mathbf{0 , 0 5 4 6}$ \\
\hline SKLT & 0,2017 & 0,0935 & 0,1191 & $\mathbf{0 , 1 3 8 1}$ \\
\hline STTP & 0,2806 & 0,1722 & 0,0333 & $\mathbf{0 , 1 6 2 0}$ \\
\hline ULTJ & 0,1319 & 0,1218 & 0,0665 & $\mathbf{0 , 1 0 6 7}$ \\
\hline Rata-rata & $\mathbf{0 , 1 7 2 0}$ & $\mathbf{0 , 0 3 1 9}$ & $\mathbf{0 , 1 1 9 5}$ & - \\
\hline
\end{tabular}




\begin{tabular}{|c|c|c|}
\hline $\begin{array}{l}\text { per tahun } \\
(\mathrm{x})\end{array}$ & & \\
\hline \multicolumn{2}{|r|}{ Nilai Minimum (x) } & $-0,2044$ \\
\hline \multicolumn{2}{|r|}{ Nilai Maksimum ( $\mathrm{x}$ ) } & 0,4621 \\
\hline \multicolumn{2}{|r|}{ Rata-rata Keseluruhan (x) } & 0,1078 \\
\hline
\end{tabular}

Sumber: Laporan Keuangan Perusahaan Sub Sektor Makanan dan Minuman (Data Diolah)

Dari Tabel 2, dapat disajikan grafik sebagai berikut:

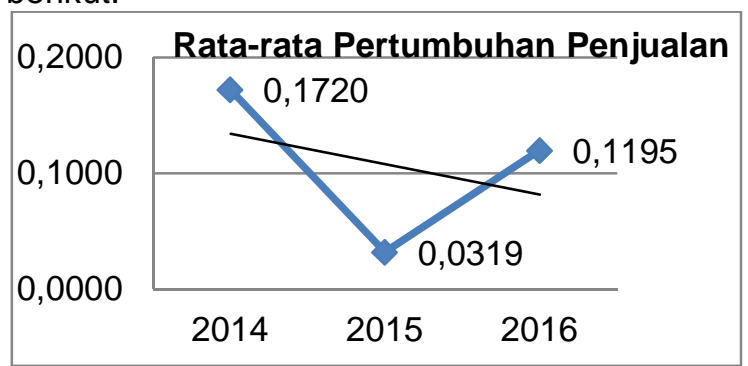

Sumber: Data Diolah

Gambar 1

Grafik Rata-rata Pertumbuhan Penjualan

Perusahaan Sub Sektor Makanan dan

Minuman yang Terdaftar di Bursa Efek Indonesia Periode 2014-2016

Berdasarkan Tabel 2 dan Gambar 1 Ratarata Pertumbuhan Penjualan Perusahaan Sub Sektor Makanan dan Minuman yang Terdaftar di Bursa Efek Indonesia Periode 2014-2016 berfluktuasi dan cenderung menurun. Rata keseluruhan nilai pertumbuhan penjualan Perusahaan Sub Sektor Makanan dan Minuman yang terdaftar di Bursa Efek Indonesia periode 2014-2016 yang diperoleh adalah 0,1078 kali atau 10,78 persen. Artinya, penjualan Perusahaan Sub Sektor Makanan dan Minuman yang terdaftar di Bursa Efek Indonesia periode 2014-2016 bertumbuh sebesar 10,78 persen.

Nilai minimum pertumbuhan penjualan terdapat pada PT Delta Djakarta, Tbk (DLTA) sebesar -0,2044 kali atau -20,44 persen pada tahun 2015. Artinya, pertumbuhan penjualan tahun berjalan turun sebesar 20,44 persen dari pertumbuhan penjualan tahun sebelumnya. Hal ini terjadi karena, penjualan tahun 2015 sebesar Rp. 699.506.819.000 turun sebesar 20,44 persen dari penjualan tahun sebelumnya sebesar Rp. 879.253.383.000. Nilai maksimum pertumbuhan penjualan terdapat pada PT Wilmar Cahaya Indonesia, Tbk (CEKA) sebesar 0,4621 kali atau 46,21 persen pada tahun 2014. Artinya, pertumbuhan penjualan tahun berjalan naik sebesar 46,21 persen dari pertumbuhan penjualan tahun sebelumnya. Hal ini terjadi karena, penjualan tahun berjalan sebesar $\mathrm{Rp}$. 3.701.868.790.192 meningkat dari penjualan tahun lalu sebesar Rp. 2.531.881.182.546.

2) Analisis Perputaran Piutang pada Perusahaan Sub Sektor Makanan dan Minuman yang Terdaftar di Bursa Efek Indonesia Periode 2014-2016
Rata-rata perputaran piutang pada Perusahaan Sub Sektor Makanan dan Minuman yang Terdaftar di Bursa Efek Indonesia periode 2014-2016 pada Tabel 3 sebagai berikut:

Tabel 3

Gambaran Perputaran Piutang pada Perusahaan Sub Sektor Makanan dan Minuman yang Terdaftar di Bursa Efek Indonesia

Periode 2014-2016

\begin{tabular}{|c|c|c|c|c|}
\hline \\
\hline $\begin{array}{l}\text { Kode } \\
\text { Emiten }\end{array}$ & $\begin{array}{c}2014 \\
(x)\end{array}$ & $\begin{array}{c}2015 \\
(x)\end{array}$ & $\begin{array}{c}2016 \\
(x)\end{array}$ & $\begin{array}{l}\text { Rata- } \\
\text { rata } \\
(x)\end{array}$ \\
\hline AISA & 4,5713 & 3,6181 & 2,9941 & 3,7278 \\
\hline CEKA & 12,3619 & 12,1192 & 15,1710 & 13,2174 \\
\hline DLTA & 5,2989 & 3,8582 & 5,2240 & 4,7937 \\
\hline ICBP & 11,6590 & 10,7718 & 9,9627 & 10,7978 \\
\hline INDF & 15,9591 & 16,4336 & 15,0463 & 15,8130 \\
\hline MLBI & 8,4438 & 9,1119 & 13,0702 & 10,2086 \\
\hline MYOR & 4,8503 & 4,6202 & 4,7461 & 4,7388 \\
\hline ROTI & 9,4960 & 9,4139 & 9,5337 & 9,4812 \\
\hline SKBM & 11,9744 & 13,3929 & 11,8949 & 12,4207 \\
\hline SKLT & 8,8467 & 8,8268 & 8,4250 & 8,6995 \\
\hline STTP & 9,1005 & 9,2768 & 8,0878 & 8,8217 \\
\hline ULTJ & 10,2581 & 10,4217 & 10,2926 & 10,3241 \\
\hline $\begin{array}{l}\text { Rata- } \\
\text { rata per } \\
\text { tahun } \\
(\mathrm{x})\end{array}$ & 9,4017 & 9,3221 & 9,5374 & - \\
\hline \multicolumn{4}{|c|}{ Nilai Minimum $(\mathrm{x})$} & 2,9941 \\
\hline \multicolumn{4}{|c|}{ Nilai Maksimum (x) } & $\begin{array}{c}16,433 \\
6\end{array}$ \\
\hline \multicolumn{4}{|c|}{ Rata-rata Keseluruhan (x) } & 9,4204 \\
\hline
\end{tabular}

Sumber: Laporan Keuangan Perusahaan Sub Sektor Makanan dan Minuman (Data Diolah)

Berdasarkan Tabel 3 dapat disajikan grafik rata-rata perputaran piutang sebagai berikut:

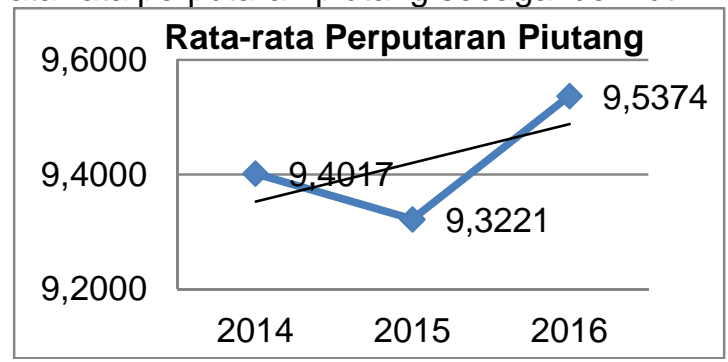

Sumber: Data Diolah

Gambar 2

Grafik Rata-rata Perputaran Piutang

Perusahaan Sub Sektor Makanan dan

Minuman yang Terdaftar di Bursa Efek Indonesia

Periode 2014-2016

Berdasarkan Tabel 3 dan Gambar 2, menunjukkan Rata-rata Perputaran Piutang Perusahaan Sub Sektor Makanan dan Minuman yang Terdaftar di Bursa Efek Indonesia Periode 2014-2016 berfluktuasi dan cenderung meningkat. Rata-rata keseluruhan nilai 
perputaran piutang Perusahaan Sub Sektor Makanan dan Minuman yang terdaftar di Bursa Efek Indonesia periode 2014-2016 yang diperoleh adalah 9,4204 kali. Artinya, tingkat perputaran piutang Perusahaan Sub Sektor Makanan dan Minuman yang terdaftar di Bursa Efek Indonesia sebesar 9,4204 kali dari penjualan dalam periode 2014-2016.

Nilai minimum perputaran piutang terdapat pada PT Tiga Pilar Sejahtera Food, Tbk (AISA) sebesar 2,9941 kali pada tahun 2016. Artinya, tingkat perputaran piutang sebesar 2,9941 kali dalam setahun dari penjualan. Hal ini terjadi karena rata-rata piutang tahun 2016 meningkat dari rata-rata piutang tahun 2015 diikuti meningkatnya juga penjualan pada tahun 2016 . Nilai maksimum perputaran piutang terdapat pada PT Indofood Sukses Makmur, Tbk (INDF) sebesar 16,4336 kali pada tahun 2015. Artinya, tingkat perputaran piutang sebesar 16,4336 kali dalam setahun dari penjualan. Hal ini terjadi karena rata-rata piutang PT Indofood Sukses Makmur, Tbk (INDF) pada tahun tersebut mengalami penurunan rata-rata piutang dari rata-rata piutang tahun 2014 .

3) Analisis Profitabilitas pada Perusahaan Sub Sektor Makanan dan Minuman yang Terdaftar di Bursa Efek Indonesia Periode 2014-2016

Rata-rata Net Profit Margin (NPM) pada Perusahaan Sub Sektor Makanan dan Minuman yang Terdaftar di Bursa Efek Indonesia periode 2014-2016 pada Tabel 4 sebagai berikut

Tabel 4

Gambaran Net Profit Margin (NPM) pada Perusahaan Sub Sektor

Makanan dan Minuman yang Terdaftar di Bursa Efek Indonesia Periode 2014-2016

\begin{tabular}{|c|c|c|c|c|}
\hline \\
\hline $\begin{array}{l}\text { Kode } \\
\text { Emiten }\end{array}$ & $\begin{array}{c}2014 \\
(x)\end{array}$ & $\begin{array}{c}2015 \\
(x)\end{array}$ & $\begin{array}{c}2016 \\
(x)\end{array}$ & $\begin{array}{l}\text { Rata- } \\
\text { rata } \\
(\mathbf{x})\end{array}$ \\
\hline AISA & 0,0736 & 0,0622 & 0,1099 & 0,0819 \\
\hline CEKA & 0,0111 & 0,0306 & 0,0607 & 0,0341 \\
\hline DLTA & 0,3276 & 0,2745 & 0,3284 & 0,3102 \\
\hline ICBP & 0,0843 & 0,0921 & 0,1054 & 0,0939 \\
\hline INDF & 0,0809 & 0,0579 & 0,0789 & 0,0726 \\
\hline MLBI & 0,2660 & 0,1843 & 0,3010 & 0,2504 \\
\hline MYOR & 0,0289 & 0,0844 & 0,0757 & 0,0630 \\
\hline ROTI & 0,1003 & 0,1244 & 0,1109 & 0,1119 \\
\hline SKBM & 0,0602 & 0,0295 & 0,0150 & 0,0349 \\
\hline SKLT & 0,0242 & 0,0269 & 0,0248 & 0,0253 \\
\hline STTP & 0,0569 & 0,0730 & 0,0662 & 0,0654 \\
\hline ULTJ & 0,0723 & 0,1191 & 0,1515 & 0,1143 \\
\hline $\begin{array}{c}\text { Rata- } \\
\text { rata per } \\
\text { tahun }(\mathrm{x})\end{array}$ & 0,0989 & 0,0966 & 0,1190 & - \\
\hline \multicolumn{4}{|c|}{ Nilai Minimum $(\mathrm{x})$} & 0,0111 \\
\hline \multicolumn{4}{|c|}{ Nilai Maksimum $(x)$} & 0,3284 \\
\hline
\end{tabular}

Rata-rata Keseluruhan (x) 0,1048

Sumber: Laporan Keuangan Perusahaan Sub Sektor Makanan dan Minuman (Data Diolah)

Berdasarkan Tabel 4 di atas, maka disajikan rata-rata Net Profit Margin (NPM) pada Perusahaan Sub Sektor Makanan dan Minuman yang Terdaftar di Bursa Efek Indonesia periode 2014-2016 sebagai berikut:

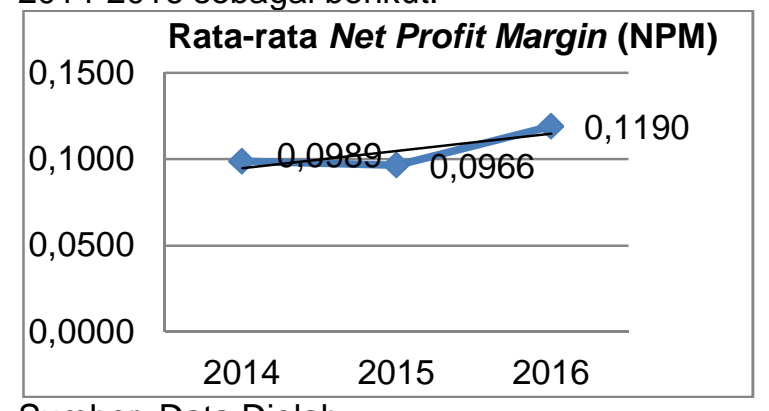

Sumber: Data Diolah

\section{Gambar 3}

Grafik Rata-rata Net Profit Margin

Perusahaan Sub Sektor Makanan dan Minuman yang Terdaftar di Bursa Efek Indonesia

Periode 2014-2016

Berdasarkan Tabel 4 dan Gambar 3 di atas rata-rata Net Profit Margin (NPM) pada Perusahaan Sub Sektor Makanan dan Minuman yang Terdaftar di Bursa Efek Indonesia periode 2014-2016 berfluktuasi dan cenderung meningkat. Rata-rata Net Profit Margin (NPM) Perusahaan Sub Sektor Makanan dan Minuman yang terdaftar di Bursa Efek Indonesia periode 2014-2016 yang diperoleh adalah 0,1048 kali atau 10,48 persen. Artinya, Perusahaan Sub Sektor Makanan dan Minuman yang terdaftar di Bursa Efek Indonesia menghasilkan laba setelah pajak sebesar 10,48 persen dari total penjualan yang dilakukan perusahaan pada periode 2014-2016.

Nilai minimum Net Profit Margin (NPM) terdapat pada PT Wilmar Cahaya Indonesia, Tbk (CEKA) sebesar 0,0111 kali atau 1,11 persen pada tahun 2014. Artinya, perusahaan tersebut menghasilkan laba setelah pajak sebesar 1,11 persen dari total penjualan yang dilakukan perusahaan atau dari Rp 1 penjualan dapat menghasilkan $\mathrm{Rp}$ 0,0111 laba setelah pajak. Hal ini terjadi karena beban yang timbul pada tahun tersebut cukup besar sehingga laba setelah pajak yang dihasilkan PT Wilmar Cahaya Indonesia, Tbk (CEKA) kecil.

Nilai maksimum Net Profit Margin (NPM) terdapat pada PT Delta Djakarta, Tbk (DLTA) sebesar 0,3284 kali atau 32,84 persen pada tahun 2016. Artinya perusahaan tersebut mampu menghasilkan laba setelah pajak sebesar 32,84 persen dari total penjualan yang dilakukan perusahaan atau dari $\mathrm{Rp} 1$ penjualan dapat menghasilkan Rp 0,3284 laba setelah 
pajak. Hal ini terjadi karena beban yang timbul pada tahun tersebut cukup kecil sehingga laba setelah pajak yang dihasilkan PT Delta Djakarta, Tbk (DLTA) besar.

\section{b. Analisis Deskrisptif Kuantitatif}

1) Regresi Linier Berganda

Pengujian analisis regresi berganda pada penelitian ini menggunakan SPSS versi 21 dengan hasil yang terlihat pada Tabel 5 .

\section{Tabel 5}

Hasil Analisis Regresi Linier Berganda

\begin{tabular}{|c|c|c|c|}
\hline \multirow[t]{2}{*}{ Model } & \multicolumn{2}{|c|}{$\begin{array}{l}\text { Unstandardized } \\
\text { Coefficients }\end{array}$} & $\begin{array}{c}\text { Standardized } \\
\text { Coefficients }\end{array}$ \\
\hline & $\mathrm{B}$ & Std. Error & Beta \\
\hline (Constant) & 193 & .039 & \\
\hline 1 Per.Penjualan & -.254 & .106 & -.371 \\
\hline Perp.Piutang & -.006 & .004 & -.266 \\
\hline
\end{tabular}

a. Dependent Variable: NPM

Sumber: Hasil Pengolahan Data

Berdasarkan Tabel 5, model persamaan regresi yang diperoleh adalah sebagai berikut:

$$
\hat{\mathbf{Y}}=0,193-0,254 \mathrm{X}_{1}-0,006 \mathrm{X}_{2}
$$

Artinya, pertumbuhan penjualan dan perputaran piutang berpengaruh negatif terhadap profitabilitas pada Perusahaan Sub Sektor Makanan dan Minuman yang Terdaftar di Bursa Efek Indonesia periode 2014-2016.

2) Koefisien Korelasi dan Determinasi

Berikut hasil pengolahan data yang menunjukkan koefisien korelasi dan determinasi pada Tabel 6.

Tabel 6

Hasil Analisis Koefisien Korelasi dan Koefisien Determinasi

\begin{tabular}{|l|c|c|c|c|}
\hline Model & $\mathrm{R}$ & $\begin{array}{c}\mathrm{R} \\
\text { Square }\end{array}$ & $\begin{array}{c}\text { Adjusted } \mathrm{R} \\
\text { Square }\end{array}$ & $\begin{array}{c}\text { Std. Error of } \\
\text { the Estimate }\end{array}$ \\
\hline 1 & $.463^{\mathrm{a}}$ & .215 & .167 & .08055 \\
\hline
\end{tabular}

Sumber: Hasil Pengolahan Data

Berdasarkan Tabel 6 nilai $r$ adalah 0,463, yang berarti hubungan yang sedang antara $\mathrm{Net}$ Profit Margin (NPM) dengan pertumbuhan penjualan dan perputaran piutang. Sementara koefisien determinasi ( $R$ Square) adalah 0,215 atau $21,5 \%$ yang berarti bahwa NPM dapat dijelaskan oleh pertumbuhan penjualan dan perputaran piutang sebesar $21,5 \%$, sedangkan sisanya yaitu sebesar $78,5 \%$ dijelaskan oleh variabel lain yang tidak diteliti dalam penelitian ini, seperti likuiditas, struktur modal dan perputaran persediaan.

\section{3) Uji Hipotesis}

a) Uji Simultan (Uji F)

Hasil uji $F$ dalam penelitian ini dapat dilihat pada Tabel 7.

Tabel 7

Hasil Uji F

\begin{tabular}{|l|c|c|}
\hline Model & F & Sig. \\
\hline
\end{tabular}

\begin{tabular}{|c|c|c|c|}
\hline 1 & $\begin{array}{l}\text { Regression } \\
\text { Residual } \\
\text { Total }\end{array}$ & 4.512 & $.019^{b}$ \\
\hline
\end{tabular}

Sumber: Hasil Pengolahan Data

Berdasarkan Tabel 7 di atas, diperoleh nilai $F_{\text {hitung }}$ sebesar 4,512 lebih besar dari $F_{\text {tabel }}$ dengan $(0,05 ; 2$ VS $(36-2-1=33)$ sebesar 3,28 , atau dengan signifikasi 0,019 lebih kecil dari $\alpha=$ 0,05 maka $H_{0}$ ditolak, yang berarti bahwa pertumbuhan penjualan dan perputaran piutang berpengaruh signifikan terhadap profitabilitas pada Perusahaan Sub Sektor Makanan dan Minuman yang terdaftar di Bursa Efek Indonesia periode 2014-2016.

b) Uji Parsial (Uji t)

Hasil uji $\mathrm{t}$ dalam penelitian ini dapat dilihat pada Tabel 8 .

Tabel 8

Hasil Uji t

\begin{tabular}{|ll|r|r|r|}
\hline \multirow{2}{*}{ Model } & $\begin{array}{c}\text { Standardized } \\
\text { Coefficients }\end{array}$ & \multirow{2}{*}{$\mathrm{t}$} & Sig. \\
\cline { 2 - 4 } 1 & \multicolumn{1}{|c|}{ Beta } & & \\
\hline \multirow{2}{*}{1} & (Constant) & & 4.924 & .000 \\
\cline { 2 - 3 } & Per.Penjualan & -.371 & -2.404 & .022 \\
& Perp.Piutang & -.266 & -1.725 & .094 \\
\hline
\end{tabular}

Sumber: Hasil Pengolahan Data

Berdasarkan Tabel 8 di atas, untuk variabel Pertumbuhan Penjualan mempunyai nilai thitung sebesar 2,404 lebih besar dari $t_{\text {tabel }}$ sebesar 2,034 dan nilai signifikansi $0,022<0,05$. Berdasarkan nilai tersebut dapat disimpulkan bahwa $\mathrm{H}_{0}$ ditolak, artinya pertumbuhan penjualan berpengaruh signifikan terhadap profitabilitas pada Perusahaan Sub Sektor Makanan dan Minuman yang terdaftar di Bursa Efek Indonesia periode 2014-2016 secara parsial.

Untuk Perputaran Piutang mempunyai nilai $t_{\text {hitung }}$ sebesar $1,725<t_{\text {tabel }}$ dengan $\mathrm{dF}=(36-2-1$ $=33$ ) sebesar 2,034 dengan nilai signifikansi $0,094>0,05$. Berdasarkan nilai tersebut dapat disimpulkan bahwa $\mathrm{H}_{0}$ diterima, artinya perputaran piutang berpengaruh tidak signifikan terhadap profitabilitas pada Perusahaan Sub Sektor Makanan dan Minuman yang terdaftar di Bursa Efek Indonesia periode 2014-2016 secara parsial.

2. Evaluasi

a. Evaluasi Pertumbuhan Penjualan pada Perusahaan Sub Sektor Makanan dan Minuman yang Terdaftar di Bursa Efek Indonesia Periode 2014-2016

Berdasarkan grafik rata-rata pertumbuhan penjualan Perusahaan Sub Sektor Makanan dan Minuman yang terdaftar di Bursa Efek Indonesia periode 2014-2016 pada Gambar 1, diketahui bahwa pertumbuhan penjualan 
cenderung menurun yang menunjukkan bahwa aktivitas penjualan dan kebijakan penjualan

Rata-rata pertumbuhan penjualan tahun 2015 mengalami penurunan. Hal ini terjadi, karena beberapa perusahaan pada tahun 2015 mengalami penurunan penjualan tahun berjalan dari penjualan tahun sebelumnya. Rata-rata pertumbuhan penjualan meningkat kembali di tahun 2016 yang menyebabkan rata-rata pertumbuhan penjualan tahun 2016 besar. Hal ini terjadi, karena beberapa perusahaan pada tahun 2016 mengalami peningkatan penjualan tahun berjalan dari penjualan tahun sebelumnya, bahkan perusahaan-perusahaan yang mengalami penurunan penjualan tahun berjalan pada tahun 2015 turut meningkat.

Perusahaan Sub Sektor Makanan dan Minuman periode 2014-2016 tidak berjalan dengan efektif. Perusahaan Sub Sektor Makanan dan Minuman periode 2014-2016 hendaknya mampu mempertahankan penjualan yang relatif besar dengan melakukan aktivitas penjualan yang konsisten, melakukan evaluasi untuk lebih mengetahui kelemahan-kelemahan yang terjadi, sehingga dapat dilakukan upayaupaya yang dapat meningkatkan penjualan seperti memproduksi produk unggulan dengan basis pelanggan yang luas.

b. Evaluasi Perputaran Piutang pada Perusahaan Sub Sektor Makanan dan Minuman yang Terdaftar di Bursa Efek Indonesia Periode 2014-2016

Berdasarkan penelitian ini, rata-rata perputaran piutang Perusahaan Sub Sektor Makanan dan Minuman periode 2014-2016 berfluktuasi dan cenderung meningkat. Hal ini menunjukkan, bahwa semakin cepat berputarnya piutang untuk kembali menjadi kas dan membiayai kegiatan operasional

Rata-rata perputaran piutang tahun 2015 Perusahaan Sub Sektor Makanan dan Minuman mengalami penurunan. Hal ini terjadi karena, beberapa perusahaan mengalami peningkatan rata-rata piutang serta penjualan perusahaan pada tahun 2015 dari tahun sebelumnya. Ratarata perputaran piutang pada tahun 2016 Perusahaan Sub Sektor Makanan dan Minuman meningkat kembali. Hal terjadi ini karena, beberapa perusahaan mengalami penurunan rata-rata piutang.

Perusahaan Sub Sektor Makanan dan Minuman yang terdaftar di Bursa Efek Indonesia periode 2014-2016 hendaknya lebih mempertimbangkan dalam hal pemberian fasilitas kredit, seperti syarat pembayaran yang diberikan. Syarat pembayaran harus disesuaikan dengan besarnya jumlah piutang agar piutang tidak menumpuk, piutang lebih cepat ditagih dan risiko piutang tak tertagih kecil dan berputarnya piutang untuk menjadi kas lebih cepat. c. Evaluasi Profitabilitas pada Perusahaan Sub Sektor Makanan dan Minuman yang Terdaftar di Bursa Efek Indonesia Periode 2014-2016

Berdasarkan hasil penelitian, nilai rata-rata Net Profit Margin (NPM) perusahaan Sub Sektor Makanan dan Minuman periode 20142016 berfluktuasi dan cenderung meningkat. Hal ini menunjukkan, bahwa semakin efektif penjualan yang dilakukan perusahaan untuk menghasilkan laba setelah pajak selama periode 2014-2016.

Rata-rata Net Profit Margin (NPM) perusahaan Sub Sektor Makanan dan Minuman pada tahun 2015 menurun dari tahun lalu. Hal ini terjadi karena, pada tahun tersebut beberapa Perusahaan Sub Sektor Makanan dan Minuman mengalami penurunan laba setelah pajak karena pada tahun 2015 beban yang timbul cukup besar akibatnya laba setelah pajak yang dihasilkan kecil. Rata-rata Net Profit Margin (NPM) perusahaan Sub Sektor Makanan dan Minuman pada tahun 2016 meningkat kembali dari tahun lalu. Hal ini terjadi, karena pada tahun tersebut beberapa Perusahaan Sub Sektor Makanan dan Minuman mengalami peningkatan penjualan tahun berjalan serta meningkatnya laba setelah pajak masingmasing perusahaan. Diikuti juga beban yang timbul pada tahun 2016 yang relatif kecil, akibatnya nilai Net Profit Margin (NPM) pada tahun 2016 besar.

Perusahaan Sub Sektor Makanan dan Minuman yang terdaftar di Bursa Efek Indonesia periode 2014-2016, hendaknya mampu mengendalikan beban-beban yang timbul setiap tahunnya agar perusahaan memperoleh laba setelah pajak lebih maksimal, sehingga Net Profit Margin (NPM) besar dan menunjukkan kemampuan perusahaan untuk memperoleh laba setelah pajak dari penjualan efektif dan efisien.

\section{d. Evaluasi Pengaruh Pertumbuhan Penjualan dan Perputaran Piutang Terhadap Profitabilitas pada Perusahaan Sub Sektor Makanan dan Minuman yang Terdaftar di Bursa Efek Indonesia Periode 2014-2016}

Berdasarkan hasil pengujian regresi linier berganda yang telah dilakukan, diperoleh persamaan regresi. Hal ini dapat dilihat dari persamaan regresi yaitu: $\hat{\mathbf{Y}}=\mathbf{0 , 1 9 3}-\mathbf{0 , 2 5 4 \mathrm { X } _ { 1 } -}$ $\mathbf{0 , 0 0 6 X}_{\mathbf{2}}$. Arti nilai 0,193 adalah apabila pertumbuhan penjualan dan perputaran piutang sama dengan nol maka Net Profit Margin (NPM) adalah sebesar 0,193 satuan. Pengaruh pertumbuhan penjualan adalah $-0,254$, artinya 
setiap peningkatan pertumbuhan penjualan sebesar 1 satuan akan diikuti penurunan Net Profit Margin (NPM) sebesar 0,254 satuan atau sebaliknya setiap penurunan pertumbuhan penjualan sebesar 1 satuan akan diikuti peningkatan Net Profit Margin (NPM) sebesar 0,254 satuan.

Hasil analisis linier berganda tersebut tidak sejalan dengan pendapat Husnan (2000:387), bahwa pertumbuhan penjualan dapat juga mempengaruhi profitabilitas perusahaan. Semakin tingginya penjualan bersih yang dilakukan oleh perusahaan dapat mendorong semakin tingginya laba kotor yang mampu diperoleh, sehingga dapat mendorong semakin tingginya profitabilitas suatu perusahaan. Apabila pertumbuhan penjualan yang tinggi maka akan meningkatkan pendapatan serta laba operasi juga akan meningkat sehingga hal tersebut akan menimbulkan peningkatan keuntungan yang diperoleh yang akan memperbesar tingkat profitabilitas.

Sementara besarnya pengaruh perputaran piutang terhadap profitabilitas sebesar $-0,006$, yang berarti bahwa ketika setiap perputaran piutang meningkat sebesar 1 satuan, maka profitabilitas akan menurun sebesar 0,006 satuan atau sebaliknya setiap perputaran piutang menurun sebesar 1 satuan, maka profitabilitas akan meningkat sebesar 0,006 satuan. Hasil tersebut tidak sejalan dengan pendapat Riyanto (2008:85), menyatakan bahwa semakin besar proporsi penjualan kredit dari keseluruhan penjualan memperbesar jumlah investasi dalam piutang. Dengan semakin besarnya volume penjualan kredit setiap tahunnya, maka perusahaan itu harus menyediakan investasi yang lebih besar lagi dalam piutang. Semakin besarnya jumlah piutang maka akan semakin besar risiko, tetapi akan memperbesar profitabilitas.

\section{KESIMPULAN DAN SARAN}

1. Kesimpulan

a. Rata-rata pertumbuhan penjualan pada Perusahaan Sub Sektor Makanan dan Minuman yang terdaftar di Bursa Efek Indonesia periode 2014-2016 adalah sebesar adalah 0,1078 kali atau 10,78 persen, nilai minimum sebesar $-0,2044$ kali atau $-20,44$ persen dan nilai maksimum sebesar 0,4621 kali atau 46,21 persen. Hal ini menunjukkan perusahaan dengan nilai pertumbuhan penjualan di atas rata-rata mengalami kenaikan penjualan periode berjalan lebih tinggi dari pada penjualan periode sebelumnya.

b. Rata-rata perputaran piutang pada Perusahaan Sub Sektor Makanan dan Minuman yang terdaftar di Bursa Efek Indonesia periode 2014-2016 adalah sebesar 9,4204 kali, nilai minimum sebesar 2,9941 kali dan nilai maksimum sebesar 16,4336 kali. Hal ini menunjukkan perusahaan diatas rata-rata mengalami penurunan rata-rata piutang yang menyebabkan nilai perputaran piutang besar.

c. Rata-rata Net Profit Margin (NPM) pada Perusahaan Sub Sektor Makanan dan Minuman yang terdaftar di Bursa Efek Indonesia periode 2014-2016 adalah sebesar 0,1048 kali atau 10,48 persen, nilai minimum sebesar 0,0111 kali atau 1,11 persen, nilai maksimum sebesar 0,3284 kali atau 32,84 persen. Perusahaan dengan nilai Net Profit Margin (NPM) di atas rata-rata mengalami peningkatan laba bersih juga diikuti besarnya penjualan.

d. Hasil regresi yang dalam penelitian ini adalah $\hat{\mathbf{Y}}=0,193-0,254 \mathrm{X}_{1}-0,006 \mathrm{X}_{2}$. Artinya Pertumbuhan Penjualan dan Perputaran Piutang berpengaruh negatif terhadap profitabilitas Perusahaan Sub Sektor Makanan dan Minuman yang Terdaftar di Bursa Efek Indonesia Periode 2014-2016.

e. Hasil koefisien korelasi ( $r$ ) dalam penelitian ini adalah 0,463 yang berarti bahwa terdapat korelasi atau hubungan yang sedang antara Net Profit Margin (NPM) dengan pertumbuhan penjualan dan perputaran piutang. Sementara koefisien determinasi $(R$ Square) adalah 0,215 atau $21,5 \%$ yang berarti bahwa NPM dapat dijelaskan oleh pertumbuhan penjualan dan perputaran piutang sebesar $21,5 \%$, sedangkan sisanya yaitu sebesar $78,5 \%$ dijelaskan oleh variabel lain yang tidak diteliti dalam penelitian ini, seperti likuiditas, struktur modal dan perputaran persediaan.

f. Hasil Uji $F$ diperoleh diperoleh nilai $F_{\text {hitung }}$ sebesar 4,512 lebih besar dari $F_{\text {tabel }}$ dengan $(0,05 ; 2$ VS $(36-2-1=33)$ sebesar 3,28, atau dengan signifikasi 0,019 lebih kecil dari $\alpha=$ 0,05 maka $\mathrm{H}_{0}$ ditolak, yang berarti bahwa pertumbuhan penjualan dan perputaran piutang berpengaruh signifikan terhadap profitabilitas pada Perusahaan Sub Sektor Makanan dan Minuman yang terdaftar di Bursa Efek Indonesia periode 2014-2016 secara simultan.

g. Hasil uji secara parsial (Uji t), pertumbuhan penjualan mempunyai nilai thitung sebesar 2,404 lebih besar dari $t_{\text {tabel }}$ sebesar 2,034 dan nilai signifikansi $0,022<0,05$. 
Berdasarkan nilai tersebut dapat disimpulkan bahwa $\mathrm{H}_{0}$ ditolak, artinya pertumbuhan penjualan berpengaruh signifikan terhadap profitabilitas pada Perusahaan Sub Sektor Makanan dan Minuman yang terdaftar di Bursa Efek Indonesia periode 2014-2016 secara parsial. Hasil Uji t perputaran piutang mempunyai nilai $t_{\text {hitung }}$ sebesar 1,725 $<t_{\text {tabel }}$ dengan $\mathrm{dF}=(36-2-1=33)$ sebesar 2,034 dengan nilai signifikansi $0,094>0,05$. Berdasarkan nilai tersebut dapat disimpulkan bahwa $\mathrm{H}_{0}$ diterima, artinya perputaran piutang berpengaruh tidak signifikan terhadap profitabilitas pada Perusahaan Sub Sektor Makanan dan Minuman yang terdaftar di Bursa Efek Indonesia periode 2014-2016 secara parsial.

2. Saran

a. Perusahaan Sub Sektor Makanan dan Minuman periode 2014-2016 hendaknya mampu mempertahankan penjualan yang relatif besar dengan melakukan aktivitas penjualan yang konsisten, melakukan evaluasi untuk lebih mengetahui kelemahankelemahan yang terjadi, sehingga dapat dilakukan upaya-upaya yang dapat meningkatkan penjualan seperti memproduksi produk unggulan dengan basis pelanggan yang luas, serta mengetahui permintaan pasar sehingga rata-rata pertumbuhan penjualan Perusahaan Sub Sektor Makanan dan Minuman periode 2014-2016 tetap konsisten dan masih dapat menghasilkan keuntungan bagi perusahaan.

b. Perusahaan Sub Sektor Makanan dan Minuman periode 2014-2016 hendaknya lebih mempertimbangkan dalam hal pemberian fasilitas kredit, seperti syarat pembayaran yang diberikan. Syarat pembayaran harus disesuaikan dengan besarnya jumlah piutang agar piutang tidak menumpuk, piutang lebih cepat ditagih dan risiko piutang tak tertagih kecil sehingga berputarnya piutang untuk menjadi kas lebih cepat.

c. Perusahaan Sub Sektor Makanan dan Minuman periode 2014-2016 hendaknya mampu mengendalikan beban-beban yang timbul setiap tahunnya agar perusahaan memperoleh laba setelah pajak lebih maksimal, sehingga Net Profit Margin (NPM) besar dan menunjukkan kemampuan perusahaan untuk memperoleh laba setelah pajak dari penjualan efektif dan efisien.

\section{E. DAFTAR PUSTAKA}

Bayangkara, IBK. 2014. Audit Manajemen. Cetakan Ketujuh. Jakarta: Salemba Empat.

Brigham, Eugene F dan Joel F. Houston. 2010.

Dasar-Dasar Manajemen Keuangan.

Buku 2. Edisi 11. Jakarta: Salemba Empat.

Harahap, Sofyan Syafri. 2008. Analisis Kritis

Atas Laporan Keuangan. Jakarta: PT Raja Grafindo Persada.

Husnan, Suad. 2000. Manajemen Keuangan

Teori dan Penerapan Keputusan Jangka

Pendek, Buku 1. Edisi Keempat.

Yogyakarta: UPP AMP YKPN

Manajemen Keuangan Teori dan

Penerapan Keputusan Jangka Pendek, Buku 2. Edisi Keempat. Yogyakarta: UPP AMP YKPN

Husnan, Suad. 2000. Dasar-dasar Teori Portofolio Dan Analisis Sekuritas, Edisi Ketiga. Yogyakarta: UPP AMP YKPN

Kasmir, 2012. Pengantar Manajemen Keuangan. Edisi Pertama,. Jakarta: Kencana.

http://www.ix.co.id/idid/beranda/perusahaantercatat/laporankeu angandan tahunan.aspx. diakses tahun 2017

Martani, Dwi, dkk. 2012. Akuntansi Keuangan Menengah Berbasis PSAK. Buku 1. Jakarta: Salemba Empat.

Riyanto, Bambang. 2010. Dasar-dasar Pembelanjaan Perusahaan. Edisi Keempat. Cetakan Keenam. Yogyakarta: BPFE.

Sudana, I Made. 2011. Manajemen Keuangan Perusahaan Teori dan Praktek. Jakarta: Erlangga. 